\title{
LAS IGLESIAS PROPIAS DE MONASTERIOS EN LA CASTILLA BAJOMEDIEVAL. ALGUNOS EJEMPLOS RIOJANOS
}

\author{
POR \\ Máximo Diago Hernando \\ Institución Milá y Fontanals, Barcelona
}

\section{ResumeN}

Los grandes monasterios benedictinos de la Rioja, especialmente San Millán de la Cogolla y Santa María de Nájera, poseyeron muchas iglesias parroquiales diseminadas por la región riojana y las montañas vascongadas y cántabras. La mayoría fueron pequeñas iglesias rurales, pero algunas de mayor tamaño, como la de Santoria o la de la capilla de la Cruz de Najera, fueron servidas por nutridas comunidades de clérigos, que mantuvieron unas relaciones muy conflictivas con sus señores los abades, las cuales son analizadas con detalle en el presente artículo.

\begin{abstract}
The monastic churches in Castile during the late Middle Ages. Some exemples taken from Rioja

The main Benedictine monasteries in the Castilian region of Rioja, namely, San Millán de la Cogolla and Santa María de Najera, possessed many parish churches, scattered throughout the region of Rioja and the mountains of the Basque Country and Cantabria. Most of them were small rural churches, but some bigger ones, like that of Santoña and the Chapel of the Cross in Najera, were served by numerous priests, who were involved in many quarrels with their lords, the abbots. Some of this quarrels are analysed in this article.
\end{abstract}

Resulta bien sabido que en los primeros siglos medievales los monasterios llevaron en gran parte de la Europa Occidental prácticamente todo el peso de 
la vida eclesiástica, y que sólo a partir de la implantación de la reforma gregoriana en la segunda mitad del siglo XI comenzaron a ceder el paso a las figuras en ascenso de los obispos y de los clérigos seculares encargados de la cura de las almas en las iglesias parroquiales.

Por efecto de esta evolución de las estructuras eclesiásticas el obispo se fue configurando como máxima autoridad religiosa del territorio diocesano, que pasó a quedar estructurado en una densa red de parroquias dependientes, en las que clérigos seculares de diversa condición estaban encargados del cuidado pastoral y de la administración de los sacramentos y sometidos a la disciplina establecida por la autoridad episcopal.

Este nuevo modelo de organización eclesiástica no logró sin embargo imponerse sin vencer previamente fuertes resistencias, $y$ en concreto fueron los monasterios los que más se opusieron a su implantación puesto que el reforzamiento de la autoridad de los obispos ponía en peligro la autonomía e independencia de la que venían disfrutando desde los siglos altomedievales, y amenazaba con poner fin al control que venían ejerciendo sobre multitud de iglesias, la mayor parte de ellas erigidas en parroquias.

El conflicto que con este motivo se planteó entre obispos y monasterios a lo largo y ancho de la Europa Occidental tras la implantación de la reforma gregoriana tuvo míltiples manifestaciones, y una de las que más han contribuido a esclarecer los historiadores ha sido la relacionada con el problema del cobro de diezmos por los monasteriosi. Este problema sin embargo estaba en la mayor parte de los casos estrechamente vinculado con el de la posesion monástica de iglesias, que en gran medida entraba en contradicción con los postulados reformistas, por tratarse en última instancia de auténticas iglesias propias que escapaban al control episcopal

$\mathrm{Y}$ de hecho a lo largo del siglo XII las discusiones en torno al derecho de los monjes a cobrar diezmos se remitían con frecuencia a otras discusiones orientadas a determinar si era compatible con la función monacal el desempeño de tareas pastorales, y si en consecuencia estaba o no justiticada la posesión por parte de los monasterios de sus propias iglesias parroquiales 2 .

Argumentos en defensa de unas y otras posturas fueron profusamente ofrecidos por los más prominentes pensadores y teólogos de la época, pero en úl1964.

1 Vid. CONSTABLE, G., Monastic Tithes from their origins to the Twelfih Century, Cambridge,

2 Ibid., pp. 138-44 y ss. Analiza los puntos de vista de San Bemardo de Claraval, que rechazaba la cura animarum para los monjes, y consideraba que éstos đebian vivir de su trabajo, no correspondiéndoles ningún derecho a cobrar diezmos. Éstos pertenecían al clérigo que servía al altar y vivía del altar. Indica este mismo autor que entre los siglos IX y XIl un número creciente de monjes ordenados desempenaron labor pastoral, pese a estar prohibida la práctica por los concilios. 
tima instancia la solución dada al conflicto estuvo mucho más determinada por factores políticos que intelectuales, y probablemente adquirió matices propios en los distintos ámbitos regionales del Occidente medieval, en función de la relación de fuerzas establecida en cada uno de ellos entre las distintas partes contendientes.

Por ello entendemos que a través de los estudios monográficos centrados en reducidos ámbitos geográficos se puede enriquecer notablemente nuestro conocimiento sobre el alcance de la reforma de la iglesia entre los siglos XI y XIII, al permitir profundizar en la identificación de los grupos sociales afectados por la misma, y determinar el grado de influencia política del que cada uno de ellos gozaba. Al mismo tiempo estos estudios proporcionan las noticias necesarias para entrar a determinar el grado de heterogeneidad que caracterizó a las instituciones eclesiásticas de la Europa pleno y bajomedieval en función de su adaptación a las condiciones sociopolíticas vigentes en sus distintos ámbitos de implantación. $Y$, aunque este últímo objetivo sólo resultaría posible alcanzarlo tras haber acometido sistemáticos estudios comparativos, no cabe duda que las monografías regionales son las que han de proporcionar el material informativo necesario para llevarlos a efecto.

Atendiendo a estos presupuestos metodológicos hemos querido con el presente trabajo de investigación, por consiguiente, realizar una pequeña aportación a la historia de la iglesia medieval desde la perspectiva del análisis de las relaciones entre clero regular y secular después de la implantación de la reforma gregoriana, circunscribiéndonos a un reducido territorio del reino de Casti1la, caracterizado en los siglos medievales por una notoria presencia de instituciones monásticas, que en varios casos continuaron desempeñando un notable papel en la vida eclesiástica de la región al contar con importantes iglesias parroquiales propias, que en gran medida escapaban al control de la autoridad episcopal correspondiente.

Se trata del territorio riojano, que por las particulares condiciones en que tuvo lugar su repoblación y estructuración política, fue un ámbito privilegiado para el florecimiento de instituciones monásticas, a las que en gran medida correspondió hasta el siglo XI tomar a su cargo la organización de la vida eclesiástica en la región ${ }^{3}$.

Por este motivo fueron muchas las iglesias parroquiales dependientes de monasterios que desde época plenomedieval existieron tanto en la Rioja como en los territorios próximos a los que alcanzaba el radio de influencia de sus

3 Vid. GaRcía DE CORTÁzAR, J. A., «Introducción al estudio de la sociedad altorriojana en los siglos X a XIV"; Berceo, 88 (1975), 3-29. También contiene algunas consideraciones al respecto su monografia El dominio del monasterio de San Millán de la Cogolla (siglos X a XIII), Salamanca, 1969. 
instituciones monásticas. Y aunque a lo largo de los siglos XII y XIII se sucedieron los conflictos con los obispos, tanto de Burgos como de Calahorra, para determinar la pertenencia de estas iglesias, los monasterios riojanos más destacados consiguieron de hecho conservar la mayor parte de ellas durante los siglos bajomedievales.

Esta circunstancia, sin embargo, dio lugar a la proliferación de innumerables conflictos durante estos últimos siglos, y a lo largo de toda la Edad Modema, tanto con los obispos como con los mismos clérigos nombrados por los abades para estar al cargo de la cura de las almas en las iglesias monacales, los cuales pusieron de manifiesto hasta qué punto entraba en contradicción con las estructuras eclesiásticas impuestas por la reforma gregoriana la posesión por las monasterios de iglesias parroquiales.

A estos conflictos vamos a prestar particular atención en el presente trabajo por el interés que ofrecen para el conocimiento de las relaciones entre clero regular y secular en la baja Edad Media castellana, aunque insistimos en que el enfoque preferentemente regional que proponemos no permite generalizar las conclusiones a las que podamos llegar.

\section{LA POSESIÓN DE IGLESIAS PARROQUIALES POR LOS MONASTERIOS RIOJANOS A FINES DE LA EDAD MEDIA}

El territorio riojano fue durante los siglos medievales un ámbito particularmente marcado por la notoria presencia de poderosos monasterios, tanto masculinos como femeninos, que extendían su área de influencia hasta el propio mar Cantábrico, en parte sobre territorios en los que no se habían consolidado poderosas instituciones eclesiásticas, como era por ejemplo el de las Vascongadas y en menor medida el de la actual provincia de Santander ${ }^{4}$.

4 Ciertamente en las actuales provincias vascas y de Santander se fundaron en los siglos plenomedievales múltiples monasterios, en su mayoría de pequeña entidad, haciendo excepción de algunos santanderinos como el de Santa María del Puerto, San Julián o Santo Toribio de Liébana. No obstante para época bajomedieval incluso estos últimos habían pasado a depender de otros grandes monasterios castellanos o leoneses. Da cuenta del fenómeno, ocurrido en el siglo XII, DíEZ HERRERA, C., La formación de la sociedad feudal en Cantabria, Santander, 1990, p. 246. Muchos pequefios monasterios vascos por su parte también fueron donados a los grandes monasterios de Santa María de Nájera y San Millán de la Cogolla. Da idea de la pequefia entidad que tenían los monasterios vascos en comparación con los riojanos a fines de la Edad Media y comienzos de la Edad Moderna un reparto de subsidio del año 1541 entre los monasterios del obispado de Calahorra en AHN, Clero, leg. 1101. De un total de $272.417 \mathrm{mrs}$. que tenían que pagar correspondió a San Millán contribuir con 75.608 mrs. y a Nájera con 43.264, de forma que entre estos dos y los otros seis monasterios riojanos de Estrella, Valvanera, Cañas, Herrera, San Prudencio y Herce entregaron casi 200.000 mrs. En contrapartida los monasterios alaveses de Barría y Quijana tan sólo contribuyeron con 6.727 mrs. y 5.444

Medievalia Hispanica

Hispania Sacra 49 (1997) 
Ciertamente no todos los monasterios riojanos medievales lograron que su correspondiente ámbito de influencia alcanzase estas elevadas cotas de extensión, sino que por el contrario fueron preferentemente los que surgieron en la primera oleada de fundaciones los que destacaron como entidades eclesiásticas con implantación netamente supracomarcal. Y más en concreto éste es el caso de los monasterios de San Millán de la Cogolla y Santa María de Nájera, que gracias a la generosidad de los reyes y nobles castellanos y navarros lograron acumular un gran patrimonio, caracterizado por una cierta dispersión territorial, al integrar bienes localizados tanto en Rioja, como en Navarra, Vascongadas, Santander y Burgos, por citar solo los ámbitos más destacados ${ }^{5}$. Otros monasterios surgidos en esta misma época, y más en concreto el de San Martín de Albelda y el de Santa María de Valvanera, no fueron sin embargo tan pródigamente dotados, y además recibieron en su mayoria bienes localizados en un entorno geográfico relativamente próximo al edificio monacal, por lo que su radio de influencia sólo con dificultad sobrepas $\delta$ el umbral comarcal ${ }^{6}$.

Pero al margen de esta constatacion interesa aquí indicar que entre los bienes con que fueron dotados estos monasterios surgidos en los siglos $\mathrm{X}$ y $\mathrm{XI}$ ocuparon un destacado lugar las iglesias rurales, dispersas por todo el extenso ámbito geográfico que acabamos de delinear, y que aún contribuyó más a ampliar la propia agregación de monasterios inicialmente «autónomos» a las grandes abadías riojanas?

No vamos a entrar aquí a analizar pormenorizadamente el proceso de incorporación de iglesias a los monasterios de la Rioja, que en su fase más expansiva se prolongó hasta el siglo XII, si bien todavía en el siglo XV se seguían

mrs. Pero además de éstos, que eran los mayores, se incluían una infinidad de pequeños monasterios del tipo de Santa María de Estíbaliz, en un tiempo dependiente de Năjera, al que le tocó contribuir con tan sólo $114 \mathrm{mrs}$.

5 Sobre el proceso de formación del patrimonio de Santa María de Najera trata la tesis doctoral de Cantera Montenegro, M., Santa María la Real de Nájera. Siglos XI-XIV, Universidad Complutense, Madrid, 1987. Sobre el proceso de formación del patrimonio de San Millán de la Cogolla trata GARCíA DE CORTÄZAR, J. A., El dominio...

6 Sobre San Martín de Albelda vid. ANDRÉs VAlERo, S., e IRADIER SANTOS, E., «El dominio de la colegiata de San Martín de Albelda» en Segundo Coloquio sobre Historia de la Rioja, Logroño, 1986, pp. 345-77. Sobre Valvanera la obra más reciente es la de GARCÍA TURZA, F. J., El monasterio de Valvanera en la Edad Media (siglos XI-XV), Madrid, 1990.

7 En este último sentido hay que destacar por ejemplo la incorporación del monasterio de Santa María del Puerto al monasterio de Santa María de Nájera en 1156, que conllevó la entrada en dependencia respecto a este último de numerosas iglesias parroquiales en el territorio de Trasmiera. Aportan datos sobre la historia de este monasterio previa a su incorporación DíEZ HERRERA, C., op. cit., y LORING, M.* I., «La restauración de Santa María del Puerto y el rey García de Nájera: un caso de encomendación monástica», En la Espafia medieval. IV. Estudios dedicados al profesor $D$. Angel Ferrari Nínez, t. I, Madrid, 1984, pp. 537-64. 
efectuando algunas incorporaciones aisladas, aunque en su mayoría de signo bastante diferente al de las de época plenomedieval, por tratarse frecuentemente de iglesias sin parroquianos, correspondientes a términos despoblados ${ }^{8}$. De hecho nuestro interés en el presente trabajo no radica en determinar cuál fue el papel de los monasterios riojanos en las estructuras eclesiásticas plenomedievales, y por ello el seguimiento del proceso de incorporación de iglesias no nos interesa en cuanto tal sino por los efectos que tuvo sobre la posición de estos monasterios en las estructuras eclesiásticas de la Baja Edad Media.

Y a este respecto interesa llamar la atención sobre algunos aspectos singulares que presentaban determinados monasterios de la Rioja en esta última época, y que eran resultado de su herencia plenomedieval. En primer lugar hay que destacar la posición singular del monasterio de Santa María la Real de Nájera, el único de los grandes monasterios riojanos ubicado en un importante núcleo urbano, que albergaba una floreciente comunidad de mercaderes ${ }^{9}$. Sobre esta ciudad el monasterio no llegó sin embargo a ejercer, en contra de lo que solía ser habitual, el señorío jurisdiccional, de forma que durante la mayor parte de la época medieval su población se organizó políticamente en un concejo autónomo, sometido directamente a la autoridad regia, aunque frecuentemente coartado en su capacidad de acción por la presencia de poderosos «tenentes» ${ }^{10}$, hasta que a mediados del siglo XV perdió definitivamente su independencia a raíz de la consolidación del señorío de los Manrique sobre Nájera ${ }^{11}$.

Esta limitación en el ejercicio de la jurisdicción civil, que ciertamente coartó la capacidad de acción política del monasterio y en ciertos momentos de los siglos XIV y XV colocó a sus prelados en una posición insegura ante las

8 Es el caso por ejemplo de las iglesias de San Millan de Villarrica y San Pedro de Ruego que fueron incorporadas al monasterio jerónimo de Santa María de la Estrella por Nicolás V en 1454 a iniciativa del obispo de Calahorra. Noticia en AHN, Clero, leg. 3152.

9 Hay que lamentar la casi total carencia de estudios monográficos sobre la ciudad de Najera en época bajomedieval. Son varios los indicios documentales no obstante que revelan que su comunidad de mercaderes y hombres de negocios era ya importante a fines del siglo XV. Sobre la importancia de los mercaderes laneros en la Nájera de la segunda mitad del siglo XVI vid. BRUMONT, F., «La laine dans la région de Nájera (deuxième moitié đu xviē siècle», en Actas del II Coloquio de Metodología Histórica Aplicada: la documeneación notarial y la Historia, t. II, Santiago de Compostela, 1984, pp. 317-22.

10 Hay que destacar la presencia de distintos representantes del linaje de Haro en la tenencia de Nájera a to largo del siglo XIII. Se puede seguir a través de la documentación publicada por RoDRÍGUEZ R. DE LAMA, I., Colección Diplomática Medieval de la Rioja, t. IV, Logron̄o, 1989.

11 Para las presiones ejercidas por la nobleza regional sobre Najera a lo largo del siglo XV vid. nuestro artículo «Linajes navarros en la vida política de la Rioja bajomedieval: el ejemplo de los Estúnigas: Príncipe de Viana, 197 (1992), pp. 563-81.

Medievalia Hispanica

Hispania Sacra 49 (1997) 
ambiciones expansionistas de la nobleza regional ${ }^{12}$, quedó sin embargo en cierta medida compensada por el hecho de que el monasterio y los prelados ejercían prácticamente sin limitaciones la jurisdicción eclesiástica sobre los feligreses najerenses, parroquianos de la llamada capilla de la Cruz, nombrando a los clérigos encargados de la cura de las almas de éstos e imponiendo la disciplina eclesiástica tanto a unos como a otros, sin intervención de los oficiales del obispo de Calahorra ${ }^{13}$.

A este respecto el monasterio de Santa María de Nájera ofrece por consiguiente un interesante contraste con el cercano monasterio burgalés de San Salvador de Oña por cuanto éste consiguió mantener en época bajomedieval el señorío jurisdiccional sobre la población de la villa donde estaba ubicado, pero por el contrario tuvo que tolerar la presencia en la misma de la iglesia parroquial de San Juan, desde la que un cabildo de clérigos sometidos directamente a la autoridad del obispo de Burgos tenf́a a su cargo la cura de almas de la población local ${ }^{14}$.

Tanto una situación como otra eran propicias para que se planteasen conflictos, y de hecho éstos proliferaron durante los siglos XIV y XV tanto en Oña como en Nájera, si bien en el primer caso los más significativos fueron los planteados con motivo de los intentos de acabar con el señorío jurisdiccional del monasterio sobre Oña, que fueron protagonizados tanto por la alta nobleza como por la propia población concejil ${ }^{15}$, mientras que en el caso de Nájera fueron los intentos de emancipación de los clérigos seculares de la capilla de la Cruz, decididamente apoyados en su última fase por los Manrique, señores de la ciudad, los que alcanzaron mayor relevancia.

12 Analizamos esta cuestión en nuestro artículo «El intervencionismo nobiliario en los monasterios riojanos durante la Baja Edad Media. Encorniendas y usurpaciones», Hispania, 182 (1992), pp. 811-61.

13 Así fue reconocido en la sentencia de don Roberto de Moya, deán de Córdoba y arcediano de Nájera, juez comisionado por el obispo de Calahorra, Diego de Zúñiga, en 1412. Sentencí que el obispo de Calahorra, atendiendo a los privilegios de Cluny, no tenía jurisdicción, corrección ni visitación en los clérigos y capellanes de la capilla de Santa Cruz e iglesia de San Miguel en Najera, ni en las otras iglesias pertenecientes al monaterio de Santa María de Najera, entre las que mencionaba las de Bezares, Arenzana de Suso, Cirueña y Santa Coloma. Reconoció expresamente que correspondía a este monasterio la jurisdicción eclesiástica sobre la villa de Nájera, y más en concreto sobre las parroquias de la capilla de la Santa Cruz y de San Migurel, pudiendo conocer todas las causas civiles, criminales, beneficiales y matrimoniales, y proceder por censura eclesíástica. Al obispo se le reconocía no obstante jurisdicción ordinaria en estas dos parroquias al igual que en la de \$an Jaime. De esta cláusula se deduce por consiguiente que esta última no estaba sometida al monasterio najerense. Una copia entre otras muchas de esta sentencia de 23-II-1412 en AHN, Clero, leg. 2960. y ss.

I4 Vid. RUIz GÓMEZ, F., Las aldeas castellanas en la Edad Media, CSIC, Madrid, 1990, pp. 271

is Ibid., pp. 313 y ss. 
El monasterio de San Millán de la Cogolla por su parte, ubicado en un entorno de carácter menos netamente urbano que el de Santa María de Nájera, consiguió sin embargo poder aunar el ejercicio tanto de la jurisdicción civil como de la eclesiástica sobre la población de los distintos núcleos consolidados en el entorno del edificio monástico ${ }^{16}$. Y esta situación también dio lugar a la aparición de conflictos con sus vasallos tanto clérigos como laicos, si bien éstos no alcanzaron una gravedad semejante a los de Oña, para el caso de conflictos con laicos ${ }^{17}$, ni a los de Nájera para el caso de conflictos con clérigos, probablemente porque la inexistencia de un núcleo urbano importante en el que se pudiesen consolidar poderosos cabildos de clérigos o ambiciosas oligarquías concejiles no favorecía el desarrollo de grandes movimientos de desafío político a la autoridad monástica, aunque en contrapartida sí que abundaron más los conflictos relacionados con el aprovechamiento agropecuario del territorio ${ }^{18}$.

El monasterio de Santa María de Valvanera por fin tenía un emplazamiento netamente rural, y no se tiene constancia tampoco de que disfrutase de derechos de patronazgo sobre iglesias de su entorno más próximo, ni siquiera en la villa de Anguiano, recuperada para el señorío monástico de manos de los Manrique a principios del siglo XVI, y en la que el cabildo de clérigos sólo estaba sometido a la autoridad del abad en el ámbito de la jurisdicción civil y crimi-

16 Hay que destacar en el entorno más inmediato del monasterio las llamadas villas y lugares del valle de San Millán, que eran Barrionuevo, Madriz, Berceo, Estollo, Santurde, San Andrés y el Río. Sobre el señorío solariego y jurisdiccional que allí ejercía el monasterio hay bastantes datos en AHN, Clero, leg. 3099. Sobre el reconocimiento de los derechos eclesiásticos en las iglesias del valle que correspondían al mismo monasterio hay recopilada bastante información documental en AHN, Clero, leg. 3107. Se transcriben varios privilegios, entre los que destaca el del obispo de Calahorra don Rodrigo del año 1182, el breve de Inocencio III de 1119 , la bula de los 11 sellos de 1246 y el breve de Alejandro IV de 1259 . Estos privilegios hacen referencia también a otras muchas iglesias que el monasterio de San Millán poseía en el obispado de Calahorra.

17 Hay que destacar por su virulencia el conflicto que enfrentó al monasterio con los concejos del valle de San Millán a partir de 1505. Numerosas referencias al mismo en AGS, RGS, y en CámaraPueblos, leg. 17, SAN MILIÁAN.

18 Un primer conflicto con los clérigos del cabildo del valle de San Millán fue resuelto por una sentencia arbitraria de 5-IX-1412. Los motivos del conflicto no estaban relacionados con el ejercicio de la jurisdicción eclesiástica por la parte del monasterio sobre los clérigos, sino que se referían a reparto de diezmos y cobro de derechos señoriales como la marzazga. También se reguló el régimen de compafteria establecido entre ambas partes, por virtud del cual los clérigos debían asistir a ciertas ceremonias litúrgicas celebradas en el monasterio, y los monjes acudir a las celebraciones de misas nuevas y entierros de los clérigos. De nuevo nos consta que se enturbiaron las relaciones entre ambas partes con motivo del conflicto con los vasallos del valle, llegando el monasterio a denunciar a los clérigos por haber incitado a los vecinos a la rebelión. Vid. cédula del rey al abad de San Millán de 6VIII-1508 en AGS, Cámara-Pueblos, leg. 17, SAN MILLÁN. Y también carta de los vicarios generales del obispado de Calahorra, fechada en Vitoria, 11-XI-1506, en AHN, Clero, leg. 3081.

Medievalia Hispanica

Hispania Sacra 49 (1997) 
nal, si bien este sometimiento daba lugar a que a veces intentase intervenir en asuntos de carácter estrictamente eclesiástico ${ }^{19}$.

El resto de los monasterios, principalmente cistercienses y jerónimos, no consta que poseyesen iglesias parroquiales, ni en su lugar de ubicación ni en un entorno más o menos próximo, haciendo excepción de algunas que les fueron anexionadas en fecha bastante tardía con el objeto de incrementar sus fuentes de ingresos, pero que no llevaban aparejada función pastoral por corresponder a términos despoblados ${ }^{20}$. Y por consiguiente fueron de hecho sólo los de Santa María de Nájera y San Millán de la Cogolla los que en los siglos bajomedievales tuvieron en propiedad un importante número de iglesias parroquiales, que en la mayor parte de los casos constituían un elemento más del conjunto de derechos señoriales que les correspondían en el lugar donde se enclavaban, salvando casos excepcionales como el de la capilla de la Cruz de Nájera.

Y de hecho la mayoría de estas iglesias, parroquiales se localizaban en ámbitos rurales, preferentemente en el propio territorio riojano, donde se concentraban la mayoría de los señoríos de estos monasterios, pero también eran numerosas en otros territorios más alejados, correspondientes a las actuales provincias vascongadas y de Burgos, Cantabria y Navarra. En Cantabria en concreto se localizaba la iglesia de Santa María del Puerto, antiguo y destacado monasterio que había sido colocado bajo la dependencia de Santa María de Nájera ${ }^{21}$. En el siglo XV habían dejado de residir allí monjes, y el monasterio de Nájera había puesto a su servicio unos cuantos clérigos seculares para que se hiciesen cargo de las funciones parroquiales a cambio de la percepción de una cantidad fija o congrua, diferenciándose a este respecto por consiguiente de los clérigos de la capilla de La Cruz en Nájera, a quienes para su sustento se había cedido el derecho a la percepción de los diezmos correspondientes al abad y convento22. A este respecto los clérigos del Puerto (Santoña) disfrutaban por lo tanto de una posición de menor autonomía que sus colegas de Náje-

19 Assí lo denunció por ejemplo en 1510 el bachiller Juan García, clérigo, en nombre de todos los clérigos y beneficiados de Anguiano. En concreto manifestó que el abad estaba contra ellos porque un racionero de Santo Domingo de la Calzada había impetrado un beneficio en Roma para una iglesia de la villa, y los clérigos no le habían querido recibir porque la designación se había efectuado en contra de la costumbre del obispado, que reservaba los beneficios para los «hijos naturales» de las correspondientes iglesias. Presurniblemente el abad de Valvanera apoyaría la candidatura del racionero, y para castigar la actitud de rebeldía de los clérigos les agraviaba a través de los oficiales de la justicia que como a señor le correspondía nombrar en Anguiano. Por ello los clérigos acudieron a los reyes denunciando que en estas condiciones no podian alcanzar cumplimiento de justicia en esa villa. Vid. AGS, RGS, XII-1510, comisión al corregidor de Santo Domingo de la Calzada.

20 Cfr. nota 8.

21 Cfr. nota 7

22 Desarrollamos éstas y otras cuestiones referentes a las iglesias del Puerto y a la capilla de La Cruz de Najjera en los siguientes epigrafes. 
ra, a pesar de que el factor de la distancia física que les separaba del prior y monjes jugase en su favor. Pero su condición no les permitía gestionar directamente el patrimonio de la iglesia, sino que ésta era una tarea asumida directamente desde Nájera, aunque con frecuencia era puesta en manos de arrendadores, procedentes de los grupos de hombres de negocios de las villas cántabras, quienes a cambio del pago de una cantidad fija al monasterio se encargaban de la recaudación de todas las rentas.

No obstante los clérigos del Puerto, a pesar de la mayor precariedad de su posición en comparación con la de los clérigos de la capilla de la Cruz, resultaron para el monasterio de Santa María tanto o más díscolos que estos últimos, sobre todo en momentos coyunturales en que no existe una autoridad bien consolidada en el seno de la comunidad monástica najerense, según tendremos ocasión de demostrar con detalle más adelante.

En la mayoría de las pequeñas iglesias rurales pertenecientes a Santa María de Nájera o a San Millán de là Cogolla no fueron por el contrario ni tan frecuentes ni tan intensos los conflictos con los clérigos puestos para el desempeño de las funciones parroquiales, en muchos casos porque ni siquiera el correspondiente monasterio se mostró interesado en intervenir en su nombramiento, delegando esta tarea en laicos arrendadores de todos los derechos correspondientes a una determinada iglesia.

\section{RÉGIMEN DE GESTIÓN DE LAS IGLESIAS MONÁSTICAS}

Dado que las iglesias pertenecientes a los monasterios riojanos en los siglos bajomedievales presentaban variadas características, en función de su conđición o no de parroquias, de su localizaciónn más o menos próxima al monasterio del que dependían, y de la prosperidad económica de la comunidad de parroquianos obligada a la entrega de diezmos, no se adoptó un modelo uniforme para asegurar el cumplimiento de las funciones pastorales a las que estaban obligados los monasterios frente a sus parroquianos como titulares de las iglesias y perceptores de los diezmos.

De hecho la mayoría de las pequeñas parroquias e iglesias no parroquiales que estaban situadas en ámbitos relativamente alejados del monasterio principal fueron con frecuencia arrendadas o cedidas a censo, ya desde el siglo XIII, aunque la mayoría de loa contratos conservados corresponden a épocas posteriores y comienzan a resultar particularmente numerosos a partir del siglo $\mathrm{XV}^{23}$. Muchas

23 Un ejemplo de arrendarniento de iglesia efectuado en el siglo XIII nos lo proporciona el de la iglesia de San Martín de Gran̄ón efectuado en 1257 por el monasterio de San Millán a Don Sancho de Velasco y su mujer doña Guiomar. Vid. AHN, Clero, leg. 3083.

Medievalia Hispanica

Hispania Sacra 49 (1997) 
de estas iglesias arrendadas o encensadas se localizaban en las actuales provincias vascongadas y de Burgos y Navarra, resultando bastante menos frecuente que se arrendasen o cediesen a censo iglesias riojanas ${ }^{24}$. En la mayoría de los contratos se hacía constar que el arrendatario o censatario quedaba obligado a mantener la iglesia «cantada, iluminada y bien servida», y en algunos incluso se indicaba el número de misas que debía hacer decir a la semana y en determinadas fiestas del año ${ }^{25}$. Frecuentemente también se hacía constar que el que tomaba a renta o censo la iglesia debía pagar al capellán que la serviría y atender al pago de los impuestos eclesiásticos, tales como visitaciones o procuraciones $^{26}$, pero por el contrario nada se indicaba sobre el régimen de nombramiento de capellanes que se debía observar ${ }^{27}$.

Cabe presumir que con frecuencia serían los propios arrendatarios o censatarios los que se ocuparían de poner al capellán, dado que ellos le pagaban. Y de hecho no hay que pensar en estas capellanías como en prebendas con las que no podía premiar a los miembros de lảs clientelas eclesiásticss de los aba-

24 Entre las iglesias navarras se puede destacar la de San Jorge de Azuelo, perteneciente a Santa María de Nájera, que fue cedida a censo en 1488 al caballero navarro Rodrigo de Medrano por su vida, la de su mujer y la de uno de sus hijos. Vid. AHN, Codice 108-B, fol. 234. Entre las burgajesas de la Bureba se pueden destacar las de Cuevagallegos y San Mamés que fueron cedidas a censo junto con los derechos señoriales correspondientes al monasterio de San Millán en ambos lugares al concejo de Pancorvo en 1431 por 70 florines. Vid. AHN, Clero, leg. 3088. Entre las del norte de la actual provincia de Burgos se puede citar la iglesia y monasterio de San Medel de Taranco, en la merindad de la Tierra de Mena. Fue dada a censo en 1430 por el monasterio de San Millán a varios vecinos de Taranco. Vid. AHN, CLero, leg. 3108. Entre las iglesias vascas se puede destacar la de San Vicente de Añez en Tierra de Ayala, cedida a censo a varios vecinos de Añez en 1430. Vid. AHN, Clero, leg. 3059. Sobre los arrendamientos de iglesias santanderinas trataremos más adelante.

25 Por ejemplo en el censo de la iglesia y monasterio de San Vicente de Añez se estipula que la alumbren y canten los domingos, lunes, miércoles, viemes y sábados y las fiestas de Pascuas y de los Apóstoles. En el arrendamiento de la iglesia de Don Brulle, cerca de Villafría, perteneciente al monasterio de Najera, en 1488 el arrendatario queda obligado a alumbrar una lámpara en la iglesia los domingos y fiestas principales y a decir una misa a su costa todos los días de Nuestra Señora. Vid. AHN, Códice 108-B, fol. 236. En el arrendamiento de la iglesia de San Miguel de Albiano por el monasterio de San Millán en enero de 1515 se obliga al arrendatario a que diga dos misas rezadas en la iglesia los días de San Miguel. Vid. AHN, Clero, libro 6.059.

26 Este punto queda bien establecido en el arrendamiento de San Jorge de Azuelo (cfr. nota 24). En el arrendamiento por 3 affos por Santa María de Nájera de la iglesia también navarra de Berbenzana se advertía al arrendatario para que impidiese que la iglesia fuese visitada por los oficiales del obispo, obligándole a pagar él mismo, en caso de que no consiguiese impedirlo, los derechos de visitación. El arrendamiento de 14-IV-1496 en AHN, Códice 109-B, fol. 31.

27 Excepcionalmente consta en algunos casos expresamente en la documentación que los renteros designaban a los capellanes en nombre del monasterio titular. Es el caso de la documentación de San Esteban de Aperrigui, referente al pleito seguido entre Santa María de Najera y Ochoa, abad de Andagoia, que había obtenido un beneficio en esta iglesia de manos del provisor de Calahorra. Vid. AHN, Clero, leg. 2937 y Códice 108-B, fol. 328. 
des, puesto que dadas las condiciones en que percibían sus honorarios cabe sospechar que éstos no resultasen particularmente elevados, máxime teniendo en cuenta que la mayor parte de las iglesias que servían eran pequeñas y no dispondrían de muchos ingresos. S6́lo en casos excepcionales de grandes iglesias, como por ejemplo la de Santa María del Puerto, se puede entender que las capellanías resultasen apetecidas, pero la situación de esta iglesia presentaba un carácter excepcional, que en su momento analizaremos con mayor detalle. Y de hecho, haciendo excepción de su caso, apenas encontramos noticias referentes a pleitos seguidos por monasterios riojanos con objeto de defender sus derechos a la libre designación de los capellanes de iglesias que habían cedido a renta o censo a terceros.

En efecto parece seguro que los monasterios no tenían ningún interés en estos nombramientos, puesto que para ellos las lejanas iglesias que arrendaban representaban ante todo un elemento más en sus fuentes de ingresos, y sólo cuando éstas peligraban se preocupaban por intervenir, defendiendo por ejemplo los derechos parroquiales de sus iglesias cuando éstos no querían ser reconocidos por los parroquianos. Y así actuó en concreto el monasterio de San Millán en 1504 al pleitear con el concejo y vecinos de Salmantón, cuando éstos pretendieron erigir una pila bautismal en la iglesia de Santa María de Salmantón en perjuicio de la iglesia parroquial de San Clemente de Ovaldía, que era propia del monasterio emilianense, y a la cual estaba sometida la población de Salmantón ${ }^{28}$.

$\mathrm{Y}$ un objetivo parecido tuvo su intervención en 1505 defendiendo el carácter de parroquia de su iglesia de San Miguel de Pedroso en Belorado que no quería ser reconocido por el cabildo de clérigos de esta villa burgalesa, para así apropiarse los diezmos que hasta entonces habían correspondido al monasterio emilianense ${ }^{29}$.

28 La documentación referente a este pleito en AHN, Clero, leg. 3090 . En la sentencia dada por fray Gil de Valladolid, prior perpetuo de Santa M.' de la Merced de Valladolid, se conden 6 a los vecinos de Salmantón a que no diesen eclesiástica sepultura a ningún vecino en la iglesia de Santa Marina, salvo a niffos en esta misma iglesia. Por contrapartida se dejaba libertad a los parientes para llevar a bautizar y a enterrar a la iglesia de San Clemente de Ovaldia o a otra parroquia a la que quisiesen. Se ordenó retirar la píla bautismal de la iglesia de Santa Marina. Por una concordia posterior los vecinos de Salmantón obtuvieron licencia del monasterio de San Millán para tener «pila y enterrorio» en la iglesia de Santa María de Salmantón ofreciendo en compensación al monasterio la mitad de un dezmero que los clérigos tenían en la referida iglesia y la cuarta funeraria de todos los cuerpos que allí se sepultasen. Confirmación de la concordia por el abad el 16-XI-1504.

29 Vid. AHN, CLero, leg. 3091. Pleito entre el prior de San Miguel de Pedroso y el abad, curas y clérigos de las iglesias unidas de Belorado. Estos últimos sostenian que el lugar de San Miguel de Pedroso estaba bajo la campana de Belorado, y por ello les correspondían a ellos los diezmos. La parte contraria sostenía que a pesar de que eran vasallos del Condestable y vecinos de la villa de Belorado, los vecinos de San Miguel de Pedroso eran parroquianos y dezmeros del priorazgo de esta iglesia.

Medievalia Hispanica

Hispania Sacra 49 (1997) 
Por regla general las iglesias cedidas a censo escapaban en gran medida al control de los monasterios propietarios, a pesar de que en los contratos solía quedar bien precisada la obligación del censatario de atender debidamente al abad cuando acudiese a la correspondiente iglesia a efectuar la preceptiva visita, y de dar posada a los monjes y otros hombres del monasterio que allí acudiesen. Y sólo en algunos casos, para evitar situaciones de proliferación de individuos que reclamaban derechos sobre una misma iglesia y que se llamaban patronos de ella cuando habían sido varias las personas que la habían tomado a censo y procedían a repartos sucesorios y ventas de «participaciones» en el censo, se preocuparon los monasterios titulares por exigir en el contrato original que en el futuro el número de derechohabientes nunca excediese el establecido en el momento de la concertación del censo ${ }^{30}$. De esta manera los monasterios tratarían de evitar perder totalmente el control sobre sus iglesias encensadas, pero de hecho a veces fueron los propios censatarios los que se preocuparon por ponerse de acuerdo para poner freno al proceso de incremento del número de personas con derechos a una iglesia monacal tomada a censo, como fue el caso de los autodenominados patronos del monasterio de San Medel de Taranco, en el valle de Mena, censatarios del monasterio de San Millán de la Cogolla ${ }^{31}$.

A diferencia de las iglesias navarras, vascongadas, burgalesas y cántabras pertenecientes a los monasterios de Santa María de Nájera y San Millán de la Cogolla, las más cercanas iglesias riojanas también a ellos pertenecientes fueron sometidas a un control más directo, evitando en la medida de lo posible cederlas a renta o censo, aunque con bastante frecuencia sí se arrendasen los diezmos correspondientes a las mismas, como era política habitual por otra parte en la mayoría de las instituciones eclesiásticas de la Castilla de la época.

Por consiguiente estos monasterios, y en concreto sus abades o priores, mostraron un mayor interés por intervenir en el nombramiento de los clérigos que debían servir estas iglesias que les pertenecían en territorio riojano, a efectos tanto de poder premiar los servicios de determinados clérigos o monjes de sus clientelas, como de reforzar la influencia que ejercían sobre sus vasalos, ya que salvo excepciones las iglesias solían ser las parroquias de lugares

30 En el contrato de entrega a censo de la iglesia y monasterio de San Vicente de Añez por el monasterio de San Millán de la Cogolla a tres vecinos de Añez, nietos de un tal Ruy López de Añez, en 21-VI-1430, se incluye una cláusula que dispone que el derecho sobre la iglesia lo herede sólo uno de los sendos herederos de cada uno de ellos, de manera que el referido derecho esté siempre en solo tres personas. Vid. AHN, Clero, leg. 3059.

31 En el monasterio de San Medel de Taranco, estando reunidos los patronos del monasterio el 2 III-1511 hicieron una ordenanza para que el derecho que les correspondía sobre el monasterio como censatarios de San Millán de la Cogolla, no se pudiese dividir en adelante en más suertes de las que ya había. El censo se había concertado en 1.430. Para más detalles vid. la documentación reuniơa en AHN, Clero, leg. 3108. 
sometidos al señorío jurisdiccional y solariego de los monasterios. De hecho a la hora de elegir a los clérigos que habían de servir estas parroquias los abades debían respetar la costumbre establecida en el obispado de Calahorra de designar para los beneficios a los llamados «hijos patrimoniales», es decir a los que habían sido bautizados en la correspondiente parroquia. Pero en lo demás actuaban con absoluta libertad, y eran ellos quienes examinaban a los candidatos a clérigos y los ordenaban, designándoles después para los beneficios vacantes $^{32}$. De esta manera podían ejercer una notable influencia adicional sobre la población de sus lugares de señorío, pues en sus manos quedaba el poder facilitar o dificultar la «carrera eclesiástica» de aquellos vecinos que sintiesen inclinación por ella, mientras que en otros lugares eran los oficiales del obispo de Calahorra los que regulaban la carrera de los clérigos.

En cuanto a la utilización de los beneficios curados de estas iglesias monásticas para premiar a determinadas personas vinculadas a los abades hay que indicar que también diversos indicios documentales sugieren que era habitual. $\mathrm{Y}$ así por ejemplo consta que a fines del siglo XV y principios del XVI personas muy vinculadas al abad de Santa María de Nájera, Pablo Martínez de Unuñuela, obtuvieron beneficios curados en algunas de las principales iglesias pertenecientes a este monasterio. Es el caso de su capellán fray Diego de Silanes al que se le concedió el beneficio curado de Santa Coloma, suscitando así la enconada oposición de los parroquianos, que llegaron a rasgarle las vestiduras sagradas mientras estaba celebrando misa, y a encastillarse a continuación en la iglesia, hasta que finalmente se resolvió el conflicto por sentencia arbitral que reconoció al monasterio el derecho a proveer los servicios de la iglesia como estimase oportuno, y multó al concejo en $15.000 \mathrm{mrs}$. y a diferentes vecinos particulares en 30 ducados $^{33}$.

También es el caso de fray Juan de Unuñuela que estuvo sirviendo el beneficio curado de La Molina en el obispado de Burgos, y por fin el del licenciado de la Canal, clérigo secular que destacó como uno de los más estrechos colaboradores del abad Don Pablo, al cual se le reservaron los diezmos y réditos de la iglesia de Arenzana de Suso, aunque parece que él no la servía personalmente ${ }^{34}$.

\footnotetext{
32 Bastantes referencias al procedimiento que se seguía para la selección de los clérigos en los lugares de la jurisdicción del monasterio de Santa María de Nájera en declaraciones de testigos incluidas en prueba testifical del 1515 en AHN, Clero, leg. 3024, fols. 126, 131, 149 y 157, entre otros.

33 Referencias a estos hechos en AHN, Clero, leg. 2966.

34 Se da constancia de estos hechos en una capitulación otorgada por el abad Pablo Martínez de Unuñuela en la que se recogen las condiciones exigidas por éste para renunciar a la abadía perpetua y admitir la integración de su monasterio en la congregación observante. Entre ellas figuran que a su capellán fray Diego de Silanes se le reserve el beneficio curado que tenía en la iglesia de Santa Coloma, al licenciado de la Canal de Tricio se le reserven en vida los diezmos y réditos de la iglesia de Arenzana de Suso, y a fray Juan de Uruñuela se le mantenga el beneficio curado de La Molina, que ya

Medievatia Hispanica

Hispania Sacra 49 (1997)
} 
Los ejemplos aducidos ponen de manifiesto, por otra parte, que todavía a principios del siglo XVI no era inusual que monjes que hubiesen recibido las ordenes sagradas sirviesen iglesias parroquiales, aunque lo cierto es que los abades prefirieron a clérigos seculares para desempeñar esta función. Y así lo prueba de forma paradigmática el hecho de que en la propia iglesia mayor del monasterio de Santa María de Nájera se reservase una capilla, la llamada de La Cruz, para que allí clérigos seculares atendiesen al cumplimiento de las funciones parroquiales a las que estaba obligado el monasterio para con sus feligreses najerenses.

Esta situación dio lugar a la proliferación de conflictos entre monasterio y clérigos, que vamos a analizar con más detalle en el siguiente epígrafe, para por fin después centramos en el caso del monasterio de Santa María del Puerto y sus iglesias y ermitas dependientes, que por su peculiaridad también merece un capítulo aparte.

Por contraste con estos dos casos las relaciones de los monasterios riojanos con los clérigos que servían sus iglesias parroguiales no fueron particularmente problemáticas, y a lo sumo se registran algunos casos aislados de protestas de estos últimos por considerar insuficiente la congrua con la que se remuneraban sus servicios ${ }^{35}$, $o$ de resistencia de las comunidades de parroquianos a admitir a ciertos clérigos impuestos por el abad, como hemos visto que ocurrió en Santa Coloma a principios del siglo XVI. Ś́lo cuando intervenían iglesias de elevado rango estos problemas alcanzaban mayor virulencia, y así vamos a tener ocasión de comprobarlo en el análisis de los casos de la capilla de La Cruz de Nájera y de la iglesia de Santa María del Puerto.

\section{El CONFlicto de los ClÉrigos de la CAPILla de LA CRUZ CON EL MONASTERIO DE SANTA MARÍA LA REAL DE NÁJERA}

El monasterio najerense de Santa María la Real presentó la peculiaridad de tener a su cargo la cura de almas de un importarte número de parroquianos

\footnotetext{
venía sirviendo. El texto de esta capitulación en AHN, Códice 109-B, fols. 191-8. Para encuadrar estas noticias en su contexto remitimos a nuestro articulo «La reforma de los monasterios riojanos en el reinado de los Reyes Católicos», Hispania Sacra, 90, 1992, pp. 667-97.

35 La mayoría de las noticias sobre este tipo de conflictos corresponden al siglo XVI. Un ejemplo lo tenemos en el pleíto seguido por Bezares en la década de 1560, en que el concejo apoyó la causa de los clérigos, a fin de que se les aumentase su dotación económiça y dejasen de tener la condición de capellanes a voluntad, adquiriendo sus beneficios a título perpetuo. Vid. AHN, Clero, legs. 2939 y 2940. Problemas semejantes planté también en el siglo XVI Santa Coloma (cfr. documentación citada en nota 33). En estos conflictos hay que ver una manifestación del deseo de los concejos dependientes de seî́orío monástico de afirmar su autonomía también en el terreno eclesiástico, consiguiendo que los clérigos de sus parroquias no estuviesen tan sometidos a la autoridad de los abades.
} 
instalados en un floreciente núcleo urbano, con una diversificada estructura socioeconómica, y de haber recurrido a la colaboración de varios clérigos seculares para cumplir con esta tarea. De hecho parece que los clérigos estuvieron presentes en la comunidad najerense desde los primeros momentos de su historia, y así lo probaría una cláusula del testamento del rey García de Navaтra en la que se refería a una «Honesta clericorum congregatio». Según el punto de vista del monasterio, estos clérigos no obstante fueron desde el primer momento unos meros capellanes de los prelados y monjes, encargados de cumplir con las funciones parroquiales, y a los que en compensación se les permitió residir en el recinto monacal y recibir comida y un cierto estipendio. Al disponer Honorio III sin embargo que los clérigos seculares no pudiesen convivir «intra claustra» con los monjes, los que habían residido hasta entonces en el monasterio de Nájera debieron pasar a fijar su residencia fuera de él, aunque siguiesen desempeñando sus habituales funciones pastorales en una capilla dentro de la iglesia prinçipal del monasterio ${ }^{36}$.

Estos clérigos encargados de atender a los parroquianos del monasterio en Nájera no gozaron todos del mismo rango, sino que en principio había establecida una notable diferencia entre el capellán mayor y el resto de los clérigos o capellanes menores, que quedaba en particular traducida en una desigual participación en el producto de los diezmos y otras fuentes de ingresos anejas a la capellanía de la Cruz en su calidad de parroquia ${ }^{37}$. De hecho el monasterio siempre sostuvo que estos diezmos y derechos le pertenecían como señor de la capilla de la Cruz, y que voluntariamente los había cedido al capellán mayor, a cambio de la entrega cada año de 3 marcos de plata en señal de reconocimiento,y de otras prestaciones indicadas en las actas de nombramiento de estos capellanes, otorgadas por el prior de Nájera cuando quedaba vacante el beneficio ${ }^{38}$.

No obstante fue frecuente que los nombramientos de capellán mayor recayesen en clérigos influyentes, bastantes de ellos con formación universitaria, los cuales mostraron una resistencia cada vez mayor a someterse a la disciplina

36 Tomamos estos datos de un memorial conservado en AHN, Clero, leg. 2932.

37 Vid. por ejemplo la sentencia del prior de Najera, Don Rodirgo, del año 1404 por la que resuelve un pleito tratado ante su antecesor el prior Don Femando entre el bachiller en decretos Juan Martínez, capellán mayor de La Cruz, y los otros clérigos y capellanes menores. En AHN, Clero, leg. 3016.

38 Varios de estos nombramientos desde el año 1336 hasta el anto 1441 aparecen recogidos en AHN, Clero, leg. 3016. En concreto, según consta en estos documentos, el capellán mayor quedaba obligado a ser obediente al abad, entregar los tres marcos de plata por el día de San Martín, dar al sacristán la mitad de lo que se entregase de ofrenda, y entregar al abad el diezmo de los frutos de las heredades del monasterio labradas por los parroquianos de la capilla de La Cruz. También quedaban obligados a hacer ir a los clérigos de la capilla a las procesiones, vísperas y oficios de los reyes y rogativas, y no podían recibir a ningún clérigo en la capilla sin consentimiento del abad. En caso de que algún difunto llevase plata o par̂́os de raso o de seda el capellán debía entregarlos al abad.

Medievalia Hispanica

Hispania Sacra 49 (1997) 
eclesiástica de los prelados najerenses, y por ello recurrieron a todo tipo de argumentos para hacer ver que la capilla de la Cruz era la auténtica parroquia independiente del monasterio, y que ellos, como sus párrocos y beneficiados, sólo estaban someticos a la disciplina del obispo, al igual que el resto de los clérigos seculares de la diócesis. Y por ello en varias ocasiones, para marcar aún más sus distancias con el monasterio, recurrieron al procedimiento extremo de abandonar la capilla de la Cruz e instalarse en alguna otra ermita o iglesia de Nájera, para celebrar allí los divinos oficios y administrar los sacramentos ${ }^{39}$.

De hecho este tipo de conflictos se estuvieron sucediendo en Najera desde el siglo XIV hasta el siglo XVII, $\mathrm{y}$, ante la imposibilidad de darles una solución duradera, en el año 1751 se recurrió a la drástica medida de incorporar definitivamente al monasterio todos los bienes con los que se había ido dotando en el transcurso de los siglos la iglesia y capilla de la Cruz, suprimir el cabildo de capellanes y en contrapartida disponer que en adelante el monasterio se obligase a mantener 10 capellanes para el servício de la misa, los cuales deberían recibir un estipendio de 140 ducados y los derechos de pie de altar ${ }^{40}$. De esta manera el servicio de la parroquia se trataba de garantizar mediante el empleo de un personal estrictamente asalariado, que como consecuencia se encontraba en posición de mayor dependencia frente a las autoridades monásticas, el cual ciertamente ya se había estado empleando desde hacía varios siglos en otras iglesias dependientes del monasterio de Najera ${ }^{41}$.

Esta fue la solución final en las propias vísperas del fin del Antiguo Régimen, pero volviendo a la época que por el momento nos interesa hay que hacer constar que, aunque ciertamente los conflictos entre clérigos y monjes se sucedieron con bastante frecuencia en Nájera en los siglos bajomedievales y modernos, hubo un momento en que las circunstancias propiciaron que éstos alcanzasen un especial grado de complejidad y radicalismo. Se trató en concreto de los años que siguieron a la consolidación definitiva de la reforma observante en el monasterio de Santa María, llevada a buen fin gracias al decidido apoyo de la monarquía, y con gran pesar por cierto del duque de Nájera, señor de la ciudad y uno de los nobles más influyentes del territorio riojano ${ }^{42}$.

Éste precisamente murió en febrero de 1515, poco tiempo después de la consolidación de la reforma observante en Nájera, y la poca simpatía que los

39 Detalles sobre estas salidas de los clérigos de la capilla de La Cruz para marchar a otras ermitas de Najera y erigirlas en parroquias en el memorial citado en nota 36 (habla de hasta cinco episodios de salida). Sobre la que tuvo lugar en 1515 vid. la prueba testifical presentada por el monasterio en AHN, Clero, leg. 3024.

40 Tomamos la noticia de AHN, Clero, leg. 3023.

41 Es el caso en particular de Santa María del Puerto en Santofia, que analizaremos más adelante.

42 Analizamos con detalle el proceso en nuestro artículo citado en nota 34. 
monjes observantes sentían hacia él qued $\delta$ demostrada en la tenaz resistencia que ofrecieron a cumplir la disposición testamentaria del duque, quien deseaba que se le enterrase en el propio monasterio ${ }^{43}$. Advirtiendo esta actitud en los monjes no es de extrañar, pues, que su primogénito y segundo duque de Nájera, don Antonio Manrique, mostrase a su vez una cierta hostilidad hacia ellos, que pudo llevarle presumiblemente a promover la instalación de los franciscanos en Nájera, a la que decididamente se resistieron los benedictinos de Santa María la Real ${ }^{44}$.

Pero sin acudir a los franciscanos de fuera, en la propia ciudad de Najera contaba el duque con un influyente aliado potencial para enfrentarse a los monjes benedictinos en un sector del clero, constituido precisamente por los beneficiados de la capilla de la Cruz, que continuaban manteniendo viva su vieja aspiración de librarse de la tutela monacal. Y los episodios que ocurrieron a partir de abril de 1515 demuestran que esta alianza contra los monjes observantes se llevó a efecto, confíriendo por consiguiente una cierta peculiaridad al nuevo capítulo que a la larga serie de rebeliones de los clérigos de la capilla de La Cruz aquel año se añadió.

El origen del conflicto estuvo en aquella ocasión en un pequeño altercado de carácter litúrgico, que tuvo lugar en un día de abril de 1515, cuando el arcipreste Juan de Cabredo y otros capellanes de la capilla de Santa Cruz, sin pedir licencia al prior y convento, osaron decir misa cantada con diácono y subdiácono, a pesar de tenerlo expresamente prohibido ${ }^{45}$. Ante este desafio el prior y convento decidieron castigar a los infractores, quienes llegado el momento no obstante se resistieron por la fuerza, efectuando algunos actos de violencia sobre las propias personas de los monjes. Éstos solicitaron entonces el auxilio del corregidor de Santo Domingo de la Calzada, probablemente porque no confiaban en los oficiales de la justicia de Nájera, nombrados por el propio duque, y ante la amenaza de la llegada de aquél, el arcipreste Juan de Cabredo y los suyos huyeron de la ciudad, para volver tiempo después convenientemente armados y desafiar públicamente la autoridad del prior y monjes de Santa María la Real. De hecho Juan de Cabredo se comportó como un si de un caballero revoltoso se tratase, dada la arrogancia con la que se hacía acompanar de gente armada por las calles de Nájera, y por otra parte estuvo firme-

43 Da noticias de las resistencias del monasterio a admitir el enterramiento del duque SALAZAR Y CASTRO, L. DE, Historia geneanógica de la Casa de Lara, Madrid, 1697, t. II, libro VIII, p. 139.

44 El testamento del segundo duque de Najera, Antonio Manrique, por el que se manda enterrar en la capilla mayor del monasterio de San Francisco de Nájera en RAH, Salazar y Castro, M-1, fols. $88 \mathrm{v}^{a}-92 \mathrm{r}^{\circ}$. Noticias sobre la resistencia ofrecida por el monasterio de Santa María de Najera a la instalación de los franciscanos en esta ciudad en la segunda década del siglo XVI en sendas provisiones de Carlos I de 5-IX-1517 y 14-VII-1517 en AHN, Clero, leg. 2964.

45 Vid. la prueba testifical del monasterio en AHN, Clero, leg. 3024.

Medievalia Hispanica

Hispania Sacra 49 (1997) 
mente apoyado por influyentes miembros del grupo caballeresco local, en su mayoría integrados en la clientela política del duque de Nájera ${ }^{46}$.

Ante esta situación, por consiguiente, la monarquía, decidida valedora de los intereses del reformado monasterio, tuvo que intervenir, $y$ advirtiendo que el alcalde mayor puesto por el duque de Najera no era la persona de quien se podría esperar que dispensase justicia en este caso, optó por fin en diciembre de 1515 por enviar como juez comisionado al licenciado Joanes de Ávila ${ }^{47}$. El 19 de marzo de 1516, éste finalmente dictó sentencia en favor del monasterio y contra los clérigos rebeldes y sus valedores, a muchos de los cuales se les condenó en penas pecuniarias y de destierro. A los clérigos de la capilla de la Cruz por su parte se les obligó a volver a ésta, después de que la habían abandonado para erigir en parroquia la ermita de San Pedro, y a someterse a la disciplina del abad o convento en las mismas condiciones que hasta entonces. $Y$ de esta manera se puso fin a un nuevo episodio de rebelión de estos clérigos sin hacer ninguna concesión a sus exigencias, por lo que no hay que extrañarse de que el malestar continuase y de que por consiguiente en el futuro volviesen a rebrotar estas actitudes de rebelión ${ }^{48}$.

Pero aunque el desenlace del conflicto de 1515-1516 fue semejante al de todos los que le habían precedido, y en gran medida las metas perseguidas eran las mismas que en anteriores ocasiones, éste presentó indudables peculiaridades, por la propia gravedad y carácter radical del desafio, dado que en esta ocasión los clérigos de La Cruz consiguieron el apoyo decidido de los sectores más influyentes de la sociedad política local najerense. $Y$ hasta tal punto el desafio fue grave que parece bastante probable que, de no haber recibido el monasterio el apoyo declarado de la monarquía, su autoridad eclesiástica sobre la población najerense no se hubiese podido seguir ejerciendo en las mismas condiciones que hasta entonces.

46 Así se denuncia repetidamente en las distintas declaraciones de testigos contenidas en la prueba testifical citada en nota anterior. Entre los laicos que apoyaron a Juan de Cabredo en su rebeldía figuraron el yemo del alcalde de la Mota, un paje del duque llamado Medrano, y Pedro de Cerezo, mozo de espuelas del duque, aparte de otros sólo identificados por sus nombres, que probablemente también formaban parte del círculo de servidores de la casa ducal. También se recoge la acusación que presenta al duque de Najera como directo favorecedor de los clérigos rebeldes en la provisión dirigida por la reina al corregidor de Logroto para que interviniese en el asunto. En AGS, RGS, XII-1515.

47 Copia de la carta de comisión al licenciado Joanes de Avila, fechada en.Plasencia 24-XII-1515 en AHN, Clero, leg. 3023. Consta que con anterioridad se había comisionado para que interviniesen al corregidor de Santo Domingo de la Calzada y al de Logrofio (cf. nota anterior).

48 Las sentencias del licenciado Joanes de Ávila en AHN, Clero, leg. 3023. Noticias sobre nuevos episodios de rebeldía protagonizados por los clérigos de la Cruz a lo largo de la Edad Moderna en la documentación de Nájera conservada en AHN. No se le han dedicado trabajos de investigación. 
De hecho varios de los clérigos rebeldes eran personas influyentes dentro de la organización eclesiástica secular, destacando en este sentido tanto Juan de Cabredo, arcipreste de Nájera y años más tarde juez en esta ciudad y su arciprestazgo por el obispo de Calahorra ${ }^{49}$, como Álvaro de Cabredo, arcipreste de Rioja y sobrino de Rodrigo de Cabredo, protonotario apostólico que gozaba de cierta influencia en la Corte romana ${ }^{50}$. Ciertamente los Cabredo consiguieron numerosos e importantes beneficios en el obispado de Calahorra a lo largo de todo el siglo XVI, que significativamente compatibilizaron con otros en la capilla de la Cruz, los cuales en principio debían ser provistos por el abad o prior de Santa María la Real, aunque existen motivos para sospechar que los nombramientos llegaron a veces directamente de Roma ${ }^{51}$. En cualquier caso, aunque no lo hemos podido comprobar, parece bastante probable que tuviesen relación de parentesco con uno de los últimos priores de Nájera anteriores a la reforma observante del monasterio, don Gonzalo de Cabredo, también llamado đe Vergara, al igual que el arcipreste Juan de Cabredo ${ }^{52}$, y de ahí que se encontrasen en posición favorable para obtener beneficios en las iglesias dependientes del monasterio najerense, que luego por su parte quedaba reforzada por el hecho de contar con influencias poderosas en Roma ${ }^{53}$.

Pero los Cabredo, que en unos casos estaban avencidados en Nájera y en otros en Logroño, no sólo despuntaron en la región en esta época por su éxito en la obtención de importantes beneficios eclesiásticos, sino que al mismo tiempo se dispone de indicios que sugieren que la familia también contó con destacados hombres de negocios y mercaderes que ocuparon posiciones pre-

49 En acta de 9-II-152I aparece Juan de Cabredo, alias de Vergara, como juez y vicario en Nájera y su arcedianazgo por el obispo de Calahorra. En AHN, Clero, leg. 2927.

so Rodrigo de Cabredo era protonotario apostólico, y como tal había conseguido de León $\mathrm{X}$ una bula de exención de la justicia eclesística ordinaria para sí y para todos sus parientes, por virtud de la cual podían elegir para que juzgase las causas a ellos tocantes a su propio juez apostólico conservador. Así procedió en 1516 Álvaro de Cabredo, clérigo de la capilla de La Cruz y sobrino de Rodrigo de Cabredo, en el pleito que trataba con el abad y monjes de Santa María de Najera. Vid. AHN, Clero, leg. 3013.

51 Consta expresamente que este caso se dio en 1555, cuando el doctor Cabredo impetró la capellanía mayor de Najera en Roma, y los oficiales đe la monarquía intervinieron a petición del monasterio en defensa del Real Patronazgo.

S2 El prior Gonzalo de Cabredo, alias de Vergara, falleció el 7-V-1486. Sobre su coincidencia de apellido con el arcipreste, cfr. nota 49.

53 Consta, por ejemplo, que fueron varios los parientes del protonotario Rodrigo de Cabredo que obtuvieron beneficios en iglesias del monasterio de Năjera. Además del caso de Álvaro de Cabređo, cit. en nota 50 hay que destacar el de Pedro Jiménez de Cabredo, beneficiado de la iglesia de San Nicolás de Somalo, quien en 1516 también se acogí́ al privilegio de exención, según la parte contraria para no ser corregido ni castigado por el abad de Najara de los excesos y delitos que había cometido y seguía cometiendo. Vid. AHN, Clero, leg. 2925.

Medievalia Hispanica

Hispania Sacra 49 (1997) 
eminentes en el seno de las oligarquías un tanto amplias y relativamente abiertas entonces existentes en las principales ciudades riojanas ${ }^{54}$.

Y precisamente esta doble faceta de la familia Cabredo nos viene a ilustrar una de las circunstancias que más contribuyó a conferir su peculiaridad al conflicto đe 1515-1516. Nos referimos al hecho de que los clérigos de la capilla de La Cruz que entonces se rebelaron con Juan de Cabredo a la cabeza, consiguieron el decidido apoyo de amplios sectores de la población laica local porque estaban vinculados por lazos de parentesco con algunos de los ciudadanos más influyentes, y así lo denunció expresamente el monasterio en las pruebas testificales presentadas en defensa de su causa. ${ }^{55}$

Los monjes, por el contrario, después de la imposición de la reforma observante, habían sido renovados en su práctica totalidad y traídos en su mayoría de otras zonas del reino, y por consiguiente despertarian una cierta antipatía entre la población local, y en particular quizás entre los parientes de antiguos monjes conventuales, bastantes de los cuales no habían podido ser asimilados por el monasterio reformado y conformaban una comunidad monástica paralela en Santa Coloma, llamada a la extinción porque no se le permitía incorporar nuevos miembros ${ }^{56}$.

De hecho uno de los factores que más dificultó la imposición đe la reforma observante en Santa María de Nájera radicó en el apoyo que la sociedad política local, encabezada por el propio duque de Nájera, prestó a los monjes conventuales que se resistían a someterse a la nueva disciplina, que imponía cambios de costumbres y ciertos sacrificios, en especial a los abades y priores perpetuos $^{57}$. Y por esta razón los enfrentamientos de 1515-1516 pueden ser considerados como la última manifestación de resistencia a la instalación de los monjes observantes en Nájera por parte de la sociedad política local, que los consideraba ante todo como un cuerpo extraño que se había hecho con el control de la institución eclesiástica más poderosa de la ciudad.

54 Hay que lamentar la falta de estudios dedicados a la identificación de los miembros de las oligarquías riojanas de fines de la Edad Media, la cual ciertamente resulta más difícil que en otros ámbitos del reino de Castilla porque en las ciudades de la Rioja no existía la figura de los regidores perpetuos y se daba una gran rotación en el desempeño de los oficios concejiles. Sólo disponemos de referencias documentales dispersas que nos presentan a individuos apellidados Cabredo como personas acaudalados e influyentes. Hay que destacar que a mediados del XVI una Iiménez de Cabredo se convirtí por matrimonio en señora de la villa soriana de Hinojosa de la Sierra, enlazando con el prestigioso linaje noble de los Hurtado de Mendoza.

55 Vid. AHN, Clero, leg. 3024.

56 Vid. nuestro artículo cit. en nota 34.

57 Ibid. 


\section{CONFLICTO CON LOS CLÉRIGOS DEL PUERTO (SANTOÑA)}

La incorporación del monasterio de Santa María del Puerto al de Santa María de Nájera permitió a este último contar con un importante patrimonio en la región cántabra de Trasmiera, que comprendía derechos señoriales con jurisdicción civil y criminal sobre los vecinos de la villa de Puerto (Santona), y la propiedad de la iglesia monástica de Santa María del Puerto y de otras muchas iglesias y ermitas que formaban parte de su «honor», las cuales en muchos casos tenían reconocido el carácter de parroquias ${ }^{58}$. De esta manera todavía a fines de la Edad Media el patrimonio cántabro de Santa María de Nájera era notablemente importante, y su posesión confería a este monasterio una cierta singularidad en relación al resto de los riojanos, que no gozaban de un semejante acceso al mar.

La distancia geográfica existente entre Santoña y Nájera no hacía posible sin embargo un control muy directo de este patrimonio por parte de los monjes najerenses, por lo que recurrieron con bastante frecuencia ya a lo largo de todo el siglo XV a delegar en arrendatarios y censatarios la tarea de cobrar las rentas que generaba ${ }^{59}$. En la iglesia principal de Santa María del Puerto sin embargo el monasterio tenía puestos a su servicio ocho clérigos para el desempeño de las funciones parroquiales, los cuales eran elegidos por el prior de Nájera entre los naturales y patrimoniales de la iglesia, y percibían por sus servicios una cantidad fija, que hasta 1487 había estado fijada en $2.000 \mathrm{mrs}$. para cada uno, además de las ofrendas y otros «proventos y obenciones» que desde antiguo se les habían asignado ${ }^{60}$.

Su posición era, pues, de clara subordinación al prior de Nájera, quien en ocasiones llegó a no reconocerles su condición de beneficiados perpetuos y a sostener que no eran más que simples capellanes «admovibles e ad nutum»,

59 Cfr. nota 7. Una relación de las iglesias y ermitas que pertenecían al «honor» del puerto en AHN, Clero, leg. 2982. Para una caracterización del «honor» como sistema de articulación en la Cantabria medieval, vid. DíEz HERRERA, C., op. cit., p. 39.

59 Vid. por ejemplo el contrato de arrendamiento efectuado por Gonzalo de Cabredo, prior mayor de Najera, a dos clérigos vecinos de Bárcena de todos los diezmos, infurciones y derechos pertenecientes al monasterio en el lugar de Bárcena y en las iglesias de Santa María y San Esteban, parroquias del referido lugar, por tres generaciones, a cambio de 25 florines cada af́o, y de costear los ornamentos, libros y otros objetos precisos para el servicio de las iglesias y parroquias. Fechado en Santona, 4-II-1474. Vid. AHN, Clero, leg. 2938. Otro ejemplo lo tenemos en el arrendamiento de los diezmos y otras rentas pertenecientes al monasterio en Argonos a varios vecinos de Santa María del Puerto, el 15-II-1 1494 (Ibid.).

50 En el acta de toma de posesión de la iglesia de Santa María del Puerto por el nuevo prior de Santa María de Nájera, Pablo Martínez de Uruñuela, de 10-IV-1487 se indica que los ocho clérigos que servian la iglesia habian cobrado hasta entonces $2.000 \mathrm{mrs}$. y que el prior acord6 aumentarles la dotación en 1,000 mrs. más. Este acta en AHN, Clero, leg. 2980.

Medievalia Hispanica

Hispania Sacra 49 (1997) 
que si no estaban conformes con la retribución que obtenían podían libremente abandonar la iglesia y ser sustituidos por otros ${ }^{61}$. Paradójicamente, sin embargo, para fines de la Edad Media el monasterio najerense había ya cedido su antiguo derecho a ejercer la jurisdicción eclesiástica sobre estos clérigos, y sobre todos los que servían las iglesias del «honor» de Santa María del Puerto, al obispo de Burgos, puesto que a este obispado había sido incorporado todo el territorio de Trasmiera ${ }^{62}$. Y de esta manera, aunque desde el punto de vista económico los clérigos de Santoña estaban sometidos a una mayor dependencia con respecto al monasterio de Nájera que los clérigos de la capilla de La Cruz, a los que ya nos hemos referido, por otro lado el hecho de depender del obispo de Burgos en materia de jurisdicción eclesiástica les colocaba en una posición más favorable para desafiar a la autoridad del prior a quien debían su nombramiento, puesto que en el obispo era fácil que encontrasen a un aliado, siempre interesado en debilitar a las instituciones eclesiásticas foráneas que ponían coto a su capacidad de imponer su plena autoridad' en todo el territorio diocesano.

De hecho algunos indicios documentales revelan que en la segunda mitad del siglo XV se tenía conciencia del peligro que para los intereses del prior najerense representaba el que los clérigos del Puerto y su «honor» estuviesen sometidos a la jurisdicción eclesiástica del obispo de Burgos, y no directamente a la del propio prior, como la mayoría de los clérigos de las otras iglesias propias de Nájeras, y muy en particular de las del obispado de Calahorra. Y por poner un ejemplo, podemos destacar el hecho de que, al haberse convocado en 1474 un sínodo por el obispo don Luis de Acuña, el capistol de Santa María del Puerto, que representaba los intereses del prior de Nájera, don Gonzalo de Cabredo, se mostró dispuesto a aprobar a los dos procuradores que el cabildo de esta iglesia había elegido para que la representasen en el sínodo, sólo si se garantizaba que no iban a actuar contra el monasterio najerense ni contra su prior ${ }^{63}$.

En vida de Gonzalo de Cabredo no se tiene noticia sin embargo de ningún enfrentamiento destacable entre los clérigos de Santoña y este prelado, como primera autoridad del monasterio de Nájera. Pero sí llama la atención advertir que su muerte fue inmediatamente aprovechada por los primeros para tratar de acabar de forma definitiva con la relación de dependencia que desde siglos había unido a la iglesia del Puerto con este último monasterio. En concreto

61 Estos argumentos quedan recogidos en la documentación del pleito que a fines de la decada de 1490 siguieron estos clérigos contra el monasterio de Nájera. Vid. AHN, Códice 109-B, fols. 65 y ss.

62 Tomamos la noticia de un interrogatorio de testigos realizado con ocasión de un pleito en el siglo XVI, en AHN, Clero, leg. 2981.

63 Según acta de reunión de los clérigos de Santa María del Puerto en el cementerio de la iglesia, 24-VI-1474, en AHN, Clero, leg. 2980. 
entonces, aprovechando quizás la falta de una autoridad reconocida en Santa María de Nájera, dadas las irregularidades que rodearon la elección como prior de Pablo Martínez de Uruñuela ${ }^{64}$, el capistol y los demás clérigos de Santa María del Puerto se dirigieron directamente al Consejo Real manifestando que la iglesia y su «honor» pertenecían al Real Patronato y el monasterio de Nájera había tenido ocupada la abadía. Al parecer entonces los Reyes Católicos reaccionaron nombrando al licenciado Diego de Yanguas abad de Santa María del Puerto, pero pronto el monasterio de Nájera, con Pablo Martínez de Uruñuela a su cabeza, salió en defensa de sus derechos, y tras efectuarse las averiguaciones pertinentes la monarquía terminó por ratificar la relación de dependencia de las iglesias santanderinas respecto a Santa María de Nájera ${ }^{65}$. Y por consiguiente el 10 de abril de 1487 Pablo Martínez de Uruñuela, que no había tomado posesión formal del monasterio najerense hasta el 11 de febrero de 1487 , ya acudió personalmente a Santoña a tomar posesión de la iglesia de Santa María del Puerto y de todo su «honor»66.

Entonces aprovechó también para atender algunas de las quejas de los clérigos del Puerto, que manifestaron, apoyados por los principales representantes de la sociedad política local, que las cantidades que se les entregaban en compensación por sus servicios no eran suficientes para sostenerse dignamente: $Y$ por ello el prior don Pablo, para evitar probablemente males mayores, dada la tensa situación que se había vivido en los meses precedentes, aprobó un aumento de su salario de $2.000 \mathrm{mrs}$. a $3.000 \mathrm{mrs}$. por cabeza ${ }^{67}$.

Con este aumento no quedaron sin embargo satisfechos los clérigos de Santoña, que probablemente se sirvieron en gran medida de la reivindicación de los salarios como pretexto para forzar una ruptura con el monasterio de Nájera. Y así durante toda la década de 1490 continuaron enfrentadas ambas partes con motivo de la fijación de los salarios de los clérigos, constándonos que tanto unos como otros desplegaron toda su capacidad de influencia para imponer sus criterios en la solución del conflicto. En concreto parece que los clérigos trataron de aprovechar la influencia que uno de ellos tenía tanto en ámbitos cortesanos como fuera de ellos por su condición de capellán de la reina, mientras que en contrapartida Pablo Martínez de Uruñuela no dudó en acudir a un antiguo monje de Nájera con creciente influencia en la Corte, el presentado Pedro Sánchez de Najera, futuro abad de San Benito de Valladolid, para que tratase de paralizar las actuaciones del obispo de Burgos y sus ofi-

64 Nos referimos en parte a las mismas en nuestro artículo en prensa citado en nota 34.

65 Vid. provisión de los Reyes Católicos de 9-IX-1486 en AHN, Clero, leg. 2982. También las noticias que proporciona un memorial del siglo XVIII en AHN, Clero, leg. 2901.

66 Cfr. nota 60.

67 Ibid.

Medievalia Hispanica

Hispania Sacra 49 (1997) 
ciales, puestas en marcha por los de Santoña ${ }^{68}$. De esta manera el conflicto fue ganando progresivamente en virulencia, legándose incluso a recurrir a la Corte Romana, hasta que finalmente ambas partes optaron por una solución conciliatoria, poniendo la solución del pleito en manos de un juez árbitro, el canónigo de Calahorra, licenciado Pedro Martínez de La Canal, hombre de confianza del prior de Nájera, quien en 1498 dictó una sentencia que podría ser interpretada como favorable para los intereses del monasterio riojano ${ }^{69}$. En concreto determinó que los ocho sacerdotes que servían la iglesia de Santa María del Puerto fuesen reducidos en el futuro a siete, uno de los cuales haría las funciones de sacristán. A los cinco de más rango se les incrementaba la dotación económica de 3.000 a 4.000 mrs. mientras que en contrapartida a los dos restantes se les reducía a 2.000 mrs., imponiéndoseles a todos ellos por otra parte la obligación de servir personalmente. Al prior de Nájera, que ya entonces era abad tras haberse desvinculado del monasterio de Cluny, se le seguía reconociendo el derecho a elegir a estos clérigos entre los naturales y patrimoniales de la iglesia del Puerto, pero, en contra de lo que había pretenđido, no se le autorizaba a retirarlos sin causa justa.

Esta sentencia del licenciado de la Canal puso punto final a un conflicto que ya se venía arrastrando desde hacía varias décadas, pero en absoluto contribuyó a que las relaciones entre los clérigos de Santoña y los monjes de Nájera quedasen definitivamente normalizadas, sino que por el contrario, al igual que ocurrió en el caso de los clérigos de la capilla de La Cruz, las tensiones entre ambas partes se prolongaron hasta el final del Antiguo Régimen, poniendo así de manifiesto hasta qué punto estructuras eclesiásticas consolidadas en época plenomedieval consiguieron resistir el paso de los siglos.

No obstante, tampoco éstos transcurrieron en vano, y si bien por un lado el monasterio de Nájera consiguió mantener bajo su directa dependencia a los clérigos de Santa María del Puerto, y por extensión a todos los de las iglesias y ermitas que formaban parte de su «honor», su capacidad para sacar provecho de la gestión del patrimonio de estas instituciones eclesiásticas quedó ya considerablemente mermada desde principios del siglo XVI. Y así nos lo ponen de manifiesto los censos perpetuos que, poco después de la consolidación de la reforma observante en el monasterio, éste concertó con destácados representantes de la sociedad política local de Santoña y Laredo, cediéndoles a perpe-

\footnotetext{
68 Carta del abad de Najera al «devoto hernano presentado» de 20-V-1494 en AHN, Clero, leg. 2980.

69 Existen multitud de copias de la sentencia del licenciado de la Canal de 1498. Por ejemplo en AHN, Clero, leg. 2979, y Códice 109-B, fols. 65 y ss.
} 
tuidad los diezmos y rentas del honor de Santa María del Puerto a cambio de la entrega de una cantidad fija anual ${ }^{70}$.

Ciertamente ya con anterioridad se había recurrido con bastante frecuencia a estos procedimientos de recaudación, si bien en la mayor parte de los casos se concertaban para períodos de tiempo relativamente cortos. Ahora sin embargo, a comienzos de la segunda década del siglo XVI, la cesión del derecho de cobro de diezmos y rentas pasaba a hacerse a perpetuidad, y por tratarse en consecuencia de una decisión de largo alcance hubo de obtenerse la preceptiva autorización de Roma para llevarla a efecto. Por otro lado, diversos indicios sugieren que la concertación de estos censos no fue enfocada como una operación de carácter exclusivamente económico, sino que los factores políticos intervinieron también de forma tanto o más decisiva. $Y$ así se hace constar expresamente en un documento en que uno de los que tomaron a censo perpetuo los diezmos y rentas del honor de Santa María del Puerto reconoció que el licenciado Clemente de Escalante, vecino de Laredo, miembro del Consejo Real y alcalde mayor en el reino de Galicia, había mostrado mucha diligencia para que el contrato se hiciese y llegase a efecto, gastando en la empresa mucho dinero ${ }^{71}$.

\section{CONCLUSIÓN}

Atendiendo a los casos analizados se ha podido comprobar cómo los dos monasterios riojanos que a principios del siglo XVI sobresalían por encima del resto por su destacada posición económica, coincidían en ser los que contaban con mayor número de iglesias parroquiales entre sus propiedades. Esta constatación sugiere que estas iglesias debían representar importantes fuentes de ingresos, y de hecho se constata que lo eran, dado que solían llevar aneja la propiedad de tierras y otros bienes y a la vez garantizaban la percepción de

70 La carta de censo enfitéutico perpetuo de los frutos y rentas de la iglesia de Argoños, perteneciente al honor del Puerto, de 29-IV-1513, otorgada a favor de Hernando de Setién, Ruy Sánchez de Garvijos y Juan García del Hoyo en AHN, Clero, leg. 2898. Se hace constar en ella que estos censatarios habian prestado al monasterio $\mathbf{1 . 0 0 0}$ ducados que este debía enviar a Roma para conseguir su definitiva incorporación a la congregación observante. En un acta de Burgos, 26-IX-1515 que recoge una solicitud presentada por el licenciado Clemente de Escalante al abad de San Benito de Valladolid, fray Pedro de Nájera, se hace alusión a un contrato de censo enfitéutico concertado con los tres anteriores y un cuarto individuo, el comendador Francisco de Anzillo, todos vecinos de Santona, de las rentas del honor de Santa María del Puerto, que a tenor de estos datos debí6 concertarse separadamente del de las rentas de Argoños. Vid. AHN, Clero, leg. 2943.

7 Documento otorgado por el capitán Juan del Hoyo, y por Gregorio de Setién, hijo de Hemando de Setién, en favor del licenciado Clemente de Escalante, en Santoña 28-IV-1526, en AHN, Clero, leg. 2943.

Medievalia Hispanica

Hispania Sacra 49 (1997) 
diezmos. No obstante las iglesias parroquiales que poseían los monasterios de Nájera y San Millán a fines de la Edad Media presentaban unas características muy variadas, comprendiendo desde pequeñas y remotas iglesias rurales del ámbito vasco hasta parroquias de destacados núcleos urbanos. Y por esta razón la problemática a que dio lugar su gestión por parte de estos grandes monasterios riojanos fue de carácter muy distinto de unas a otras, destacando por su peculiaridad los casos de dos complejos parroquiales dependientes del monasterio de Nájera, en los que se consolidaron poderosas comunidades de clérigos seculares que reiteradamente trataron de librarse de la situación de dependencias respecto a las autoridades monásticas en que se encontraban, y que fueron el de la capilla de la Cruz de la propia ciudad de Nájera,y el de la iglesia de Santa María del Puerto en Santoña. En ambos casos los conflictos alcanzaron especial virulencia a fines del XV y principios del XVI, pero se siguieron arrastrando hasta el propio siglo XVIII, y sólo la profunda reforma de la Iglesia en el siglo XIX les pudo poner fin. 